\title{
TITLE INDEX OF VOLUME 26
}

\section{EDITORIALS}

l, 57, 137, 191, 239

\section{United Nations Activities}

\section{UN}

- No Action on Landmines

- International Criminal Law and the Environment 192 (G. Loibl and M. Reiterer)

- UN Volunteers and Climate Change Secretariats Inaugurated

UN/CSD

- Intergovernmental Panel on Forests

- One Year Before the Review

- Intergovernmental Panel on Forests

UN/ECA

- Functions and Organisation of the Secretariat

UN/ECE

- Sofia Ministerial Conference - "Environment for Europe" -

- Progress of EIA Convention

- Committee on Environment Policy: 3rd Session

UN/FCCC

- Sign of Progress

(S. Oberthür)

- The Second Conference of the Parties (S. Oberthür)

UN/GA

- Environment and Development Related Aspects 58

- Resolutions on Human Rights

UN/ILC

- Crimes Against the Environment (C. Tomuschat)

\section{UNCLOS}

- International Tribunal

- Meeting of States Parties

- Seabed Authority: Agreement on Council

UNCTAD

- Policy Debate on trade, Environment and Development

- Midrand Conference

- Tropical Timber Agreement: Soon in Force?

\section{UNEP}

- Rio Follow-Up : Marine Environment 11

\section{OTHER INTERNATIONAL DEVELOPMENTS}

ANTARCTIC TREATY: XX Consultative Meeting 160

- Multilateral Environmental Agreements and Trade Rules

(S. Charnovitz)

- Strengthening the Application of International Environmental Law
- International Biosafety Guidelines

\section{UNEP/FAO}

- Chemicals: Negotiations on Prior Informed Consent (D. Miller)
6,240

138

152

9

FAO

- Sixth Session

Basel Convention

- Amendment Adopted on Hazardous Waste Export

CMS

- Conservation of African-Eurasian Migratory Waterbirds

- Regional Agreement -

Convention on Biological Diversity

- Second Conference of the Parties (L. Glowka)

- Food Scarcity

- Conference on Plant Genetic Resources

IAEA

- Nuclear Safety Convention in Force

ICJ

- Use or Threat of Nuclear Arms Unlawful

IMO

- Report of the 37th Session of the Marine Environment Protection Committee

- Convention on Hazardous and Noxious Substances

- Legal Committee: Liability and Compensation Issues

INCDesertification

- Eighth Session

Montreal Protocol
$\mathrm{CBD}$ : International Instruments, Processes and Non-indigenous Species Introductions: Is a Protocol to the CBD Necessary? (L. Glowka and C. de Klemm)

CEDE: Reborn!

Managing Asia's Cities

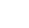


Tourism Charta

Pacta sunt servanda

24

78

(V. Koester)

Decision Making under Multilateral Environmental Agreements (P. Széll)

Elizabeth Haub Prize

Environmental Protection and the Use of Nuclear

Power Sources in Outer Space

(R.I.R. Abeyratne)

IWC: Discussions at the International Whaling

Commission

(C. Phillips)

210

207
Export of Wastes in Practice

M.T. Perez Martin)

Administrative Systems for Implementation

218

(N.A. Robinson)

Jean-Paul Harroy (1909-1995)

20

Mediterranean Sustainable Development in

International Law

(S. Marchisio)

255 Non-Aligned Movement:11th Meeting

OCDE. Environment et Mondialisation

WEC: Climate Report Criticised 175

215 WTO: Ruling on Petrol 175

\section{REGIONAL AFFAIRS}

\begin{tabular}{|c|c|c|c|}
\hline \multicolumn{2}{|l|}{ AFRICA } & - Sustainable Development in Tune with the & \\
\hline - Sustainable Development and Environment & 175 & Environment & 25 \\
\hline Council of Europe & & _ "Green" Accounting Guidelines & 93 \\
\hline - Report on European Environment Policy & 94 & - New Fishing Quotas & 176 \\
\hline EC & & - Rulings Against Italy and Greece & 176 \\
\hline - European Environment Agency & 25 & - Seveso Directive Review & 177 \\
\hline EC-EU/ECE & & - Priorities for Irish Presidency & 226 \\
\hline - State of Forests & 268 & Mediterranean States/EU & \\
\hline EEA & & - Sustainable Tourism & 26 \\
\hline - Europe's Environment : The Dobris Assessment & 26 & OAS & \\
\hline EP & & - Special Session on Environment & 225 \\
\hline - Hunting of Migrating Birds & 93 & Rhine & \\
\hline - Report on Civil Protection & 176 & - Convention on Shipping Waste & 268 \\
\hline
\end{tabular}

EU

\section{NATIONAL AFFAIRS}

\section{Bulgaria/Slovakia}

- Cooperation Agreement

Brazil

- Controversy Over New Water Highway

Canada

- Commissioner of Environment and Sustainable Development

\section{China}

- The Legal Protection of Traditional Chinese Medicinal Material Resources in China: A Brief Introduction (W. Xi)

Czech Republic

- State Environmental Policy

Germany

- Innovation and Not Restriction! (G.Becker)

- Environment Jobs

\begin{tabular}{|c|c|}
\hline \multirow{3}{*}{29} & Hong Kong \\
\hline & - Hazardous Waste Regulations \\
\hline & Mexico \\
\hline \multirow[t]{2}{*}{30} & - More Scope for Industry \\
\hline & Netherlands \\
\hline \multirow{4}{*}{107} & - The Draft Antarctic Protection Act \\
\hline & (J. Rinzoma) \\
\hline & - Soil Cleanup Increased \\
\hline & UK \\
\hline \multirow{4}{*}{269} & - Millions for Practical Measures \\
\hline & USA \\
\hline & - Spy Satellites for Environmental Monitoring \\
\hline & - Market-Based Pollution Control Regulation: \\
\hline 28 & $\begin{array}{l}\text { Implementing Economic Theory in the Real } \\
\text { World }\end{array}$ \\
\hline 10 & (R.K. Raufer) \\
\hline & - Progress in Implementing Sustainable \\
\hline 272 & Development Plan \\
\hline
\end{tabular}

272 


\section{SELECTED DOCUMENTS}

UN/GA

- 50th Session

- Resolutions and Decisions -

- Human Rights and the Environment

UN

- Commission on Crime Prevention and Criminal Justice (Resolution on Role of Criminal Law)

\section{UNCLOS}

- Meeting of States Parties (Decisions on Budgetary Matters)

\section{UNCTAD}

- Environment, International Competitiveness and Development

- Conclusions and Recommendations -

\section{UNCTAD IX}

- Declaration of the Ministerial Meeting of the LDCs

- Ministerial Declaration of the Group of 77

- African NGO Declaration

UNEP

- Marine Environment, Washington Declaration, Global Programme of Action

\section{AFRICAN MINISTERS}

- Sustainable Development and Environment (Decision)

\section{AMCEN}

- Decisions of the Sixth Session

\section{Convention on Biological Diversity}

- 14th Conference of the Parties

CSD

- International Legal Instruments and Mechanisms
EC

- Legislative and Administrative Simplification

52

- Sustainable Development in Tune with the Environment

\section{ECE}

- Ministerial Declaration

- Guidelines on Access to Environmental Infor-

FAO mental Decision-Making 34

- Leipzig Declaration

FCCC

- Review of the Implementation of the Convention and of the Decisions of the first Session of the Conference of the Parties

- Financial Mechanism

- Second Assessment Report of the Intergovernmental Panel on Climate Change (IPCC)

IMO

- International Conference on Hazardous and Noxious Substances and Limitation of Liability, 1996 (Resolutions)

Montreal Protocol

- Compliance with the Montreal Protocol by the Russian Federation

190 Non-Aligned Movement

- Heads of State or Government - Final Document - (Extracts)

- The Call from Colombia

OECD

- Environment Policy Committee

- Declaration and Resolutions

\section{AUTHORS OF SIGNED ARTICLES IN VOL. 26}

Abeyratne, R.I.R

Becker, G.

Charnovitz, S.

Glowka, L.

de Klemm, C.

Koester, V.

Loibl, G.

Marchisio, S.

Miller, D.

Oberthür, $\mathrm{S}$.
Perez Martin, M.T. $\quad 217$

Phillips, C. 215

Raufer, R.K. 177

Reiterer, M. $\quad 192$

Rinzoma, J.

Robinson, N.A. 218

Széll, P. $\quad 210$

Tomuschat, C. 242

Xi, W. 269 